\title{
ETOS KERJA DALAM PERSPEKTIF HADIS (Hadis Sosial)
}

\author{
Siti Maria Ulfah \\ Fak. Ushuluddin dan Adab UIN SMH Banten \\ alfaariaulfah@gmail.com
}

\begin{abstract}
Islam is only religion that has so high an interest in value of work, valuing workers, working hard and trying are a duty to a muslim, and avoiding idleness can become a weak one. Islam teaches hoe good works in accordance with Islamic shari, good works that do not conflict with the shara'. This is included in the work ethic. A good work ethic is in one who has faith and a strong soul. Who was always energetic and earnest in trying and doing all that is good is work in filling his life's need for prosperity. The work ethic is deep Islam deals with the values in the Qur'an and assunnah that are made up as a motive and source by every Muslim. many hadith the prophet SAW that affirms how a good work ethic should be noticed by a Muslim for the work to be done in the company of god.
\end{abstract}

\begin{abstract}
Abstrak
Islam merupakan satu-satunya agama yang sangat tinggi perhatiannya terhadap nilai kerja, menghargai para pekerja. Bekerja keras dan berusaha merupakan kewajiban bagi seorang muslim, serta dilarangnya bermalas-malasan yang dapat menjadikan seseorang menjadi pribadi yang lemah. Islam mengajarkan bagaimana cara kerja baik yang sesuai dengan syari'at Islam, pekerjaan yang baik yang tidak bertentangan dengan syara'. Hal ini termasuk dalam etos kerja. Etos kerja yang baik ada pada diri seseorang yang memiliki iman dan jiwa yang kuat, yang senantiasa bersemangat dan sungguh-sungguh dalam berusaha dan mengerjakan segala kebaikan termasuk bekerja dalam memenuhi kebutuhan hidupnya untuk mencapai kemakmuran. Etos kerja dalam Islam berkaitan dengan nilai-nilai dalam Al-Qur'an dan As-Sunnah yang dijadikan sebagai motivasi dan sumber oleh setiap Muslim. Banyak hadis Nabi SAW. yang menegaskan bagaimana etos kerja yang baik yang perlu diperhatikan oleh seorang muslim agar pekerjaan yang dilakukannya ada dalam keridhaan Allah SWT.
\end{abstract}

Kata kunci: Etos kerja; Masyarakat; Agama

\section{Pendahuluan}

Manusia merupakan makhluk sosial, maka tak heran jika dalam memenuhi kebutuhan hidupnya saling keterikatan dengan orang lain, tidak mampu berdiri sendiri. Contohnya dalam bekerja, tentunya saling berhubungan. 
Bekerja merupakan kehidupan, karena dengan pekerjaan itulah manusia bisa memenuhi kebutuhan hidupnya untuk mencapai kesuksesan dan kebahagiaan yang hakiki, baik jasmani maupun rohani, di dunia dan akhirat. Serta dengan pekerjaan itu pula hidup manusia sesungguhnya akan terasa lebih berarti. Namun, dalam bekerja untuk mencapai tujuan tersebut, tentu harus dilandasi dengan semangat bekerja yang tinggi serta tekad yang kuat agar pekerjaan itu bernilai dan tidak sia-sia. Dari agama yang ada di dunia, Islam merupakan satusatunya agama yang menjunjung tinggi nilai kerja. Islam menghargai orangorang yang berilmu, petani, pedagang, tukang dan pengrajin, ketika masyarakat di dunia pada umumnya menempatkan kelas militer dan kelas pendeta pada tingkatan paling tinggi. Karena sebagai sesama manusia, tingkatan derajat seseorang dalam Islam hanya dapat diukur dari ketakwaannya kepada Allah swt.

Kita berada pada kehidupan di era 4.0, yang mana persaingan pekerjaan antar perusahaan semakin ketat. Namun, masih banyak orang yang kurang memerhatikan pentingnya etos kerja dalam menjalankan suatu pekerjaan. Bahkan ironisnya, masih banyak yang tidak memiliki pekerjaan yang layak hingga akhirnya mereka turun ke jalan-jalan, ke tempat penziarahan, dan lainnya hanya untuk mengamen dan mengemis. Hal ini menjadi pembahasan yang menarik untuk dikaji. Oleh karenanya, dalam artikel ini akan dibahas apa sebenarnya yang dimaksud dengan etos kerja yang baik dalam pandangan Islam, serta bagaimana implementasinya dalam kehidupan masyarakat khususnya di dunia pekerjaan.

\section{Pengertian Etos Kerja}

Secara umum, menurut Clifford etos diartikan sebagai suatu aturan umum, tatanan dari prilaku atau sebagai jalan hidup dan seperangkat aturan tingkah laku yang berupaya untuk mencapai kualitas yang sesempurna mungkin. ${ }^{1}$ Etos terbentuk dari berbagai kebiasaan, pengaruh budaya, serta system nilai yang meyakininya. Kemudian dari kata etos ini dikenal kata etika yang maknanya hamper serupa dengan pengertian akhlak atau nilai-nilai kepribadian yang baik-buruk (moral).

\footnotetext{
${ }^{1}$ Clifford, Kebudayaan dan Agama, (Yogyakarta: Kanisius, 2000), 50
} 
Adapun kerja, dalam Kamus Besar Bahasa Indonesian (KBBI), kerja (dalam kata benda) berarti kegiatan melakukan sesuatu, sesuatu yang dilakukan untuk mencari nafkah. Bekerja (dalam kata kerja) berarti melakukan suatu pekerjaan atau berbuat sesuatu. ${ }^{2}$ Kerja adalah suatu usaha yang dilakukan seseorang, baik secara individu maupun kelompok untuk memproduksi suatu komoditas atau memberikan jasa kepada orang lain. Kerja memiliki makna sebagai suatu upaya untuk memenuhi kebutuhan hidupnya, baik di dunia maupun akhirat. Bukan sekedar untuk mendapatkan keuntungan materialisme duniawi seperti harta, jabatan, popularitas, dan lainnya. Namun secara hakiki merupakan suatu perintah dari Tuhan agar menjadi seorang hamba yang bermanfaat bagi hamba lainnya. Dengan bekerja, seseorang akan mendapatkan banyak pengalaman, semangat bekerja dengan dituntut untuk bekerja keras, mendapat banyak relasi, banyak teman bahkan saudara, berfikir bagaimana agar hari ini lebih baik dari kemarin dan esok lebih baik dari hari ini, berfikir kreatif serta siap menghadapi tantangan zaman.

Apabila kata etos dihubungkan dengan kerja, maka akan memiliki makna yang khas. Etos kerja, menjadi kata majemuk yang terdiri dari dua kata yang memiliki satu makna. Dua makna tersebut yaitu semangat kerja serta keyakinan seseorang dan kelompok. Etos kerja yang baik serta kualitas kepribadian sangat berpengaruh terhadap kemajuan seseorang. Oleh karenanya, etos kerja memiliki peran yang sangat penting bagi kemajuan pribadi seseorang ataupun kelompok. Setiap orang perlu menyadari bahwa kerja merupakan tanggung jawab yang besar. Bukan hanya bertanggungjawab kepada pimpinan atau manusia lainnya, tapi juga bertanggungjawab kepada Allah. Karena sungguh apa-apa yang dikerjakan manusia di dunia akan dimintai pertanggungjawaban di akhirat kelak. Itulah sebabnya mengapa kita perlu dan harus membudayakan etos kerja yang baik. Karena etos kerja berkaitan dengan sikap, akhlak, budi pekerti, serta etika dalam melakukan suatu pekerjan, maka etos kerja seseorang dipengaruhi oleh cara dia memaknai pekerjaan dalam kehidupan, serta bagaimana dia memahami hakikat kerja yang dikaitkan dengan nilai-nilai keimanan. Idealnya, pribadi yang

${ }^{2}$ Suharso dan Ana Retnoningsih, Kamus Besar Bahasa Indonesia, (Semarang: CV Widya Karya, 
dapat memaknai kerja lebih tinggi akan memiliki etos kerja terbaik. Sedangkan pribadi yang memiliki etos kerja yang baik akan memiliki semangat kerja yang tinggi, karakternya baik, dan produktifitasnya meningkat, sehingga menjadikan dirinya pribadi yang professional serta unggul yang berakhlak mulia. Hal ini sangat diperlukan karena saat ini kita yang berada pada zaman 4.0 yang mana persaingan pekerjaan semakin ketat, kompetisi antar perusahaan semakin luas, maka sangat tidak cukup jika bekerja hanya mengandalkan kemampuan otak atau akal pikiran semata, namun harus diseimbangkan dengan nilai-nilai mulia yang bersumber dari hati nurani sehingga mampu mengantarkan seseorang menjadi unggul dan professional hingga mampu sejajar dan bermitra dengan orang-orang terbaik dari seluruh dunia.

Jika berbica tentang etos kerja dalam islam, menurut Nurcholis Madjid adalah hasil suatu kepercayaan seorang muslim, bahwa kerja sangat berkaitan dengan tujuan hidupnya, untuk memperoleh ridha Allah swt. Berkaitan dengan ini, penting untuk ditegaskan bahwa Islam adalah agama amal atau kerja (praxis). ${ }^{3}$ Sedangkan menurut Toto Tasmara, dalam bukunya Etos Kerja Pribadi Muslim, bekerja adalah suatu usaha dengan tekad kuat, dengan mengerahkan segala asset, pemikiran, serta dzikirnya untuk mengaktualisasikan atau menunjukkan arti dirinya sebagai hamba Allah yang harus menundukkan dunia dan menempatkan dirinya sebagai bagian dari khairul ummah (masyarakat yang terbaik) atau bisa dikatakan jika manusia bekerja ia bisa memanusiakan dirinya. ${ }^{4}$

Toto juga mendefinisikan etos kerja dalam Islam bagi kaum muslim adalah: "Cara pandang yang diyakini seorang muslim bahwa bekerja itu bukan saja untuk memuliakan dirinya, menampakkan kemanusiannnya, tetapi juga sebagai suatu manisfestasi dari amal shaleh, dan oleh karenanya mempunyai nilai ibadah yang sangat luhur. "5

\section{Pekerjaan yang Paling Baik}

\footnotetext{
${ }^{3}$ Nurcholis Madjid. Islam Agama Kemanusiaan: Membangun Tradisi dan Visi Baru Islam Indonesia. (Jakarta: Pramadina, 1995) hal. 216

${ }^{4}$ Toto Tasmara, Etos Kerja Pribadi Muslim, (Yogyakarta: Dana Bhakti Prima Yasa, 1995), hal.

${ }^{5}$ Toto Tasmara. Etos Kerja Pribadi Muslim. hlm, 28
} 
Tahukah kamu? Islam itu indah. Ia selalu memberi pengajaran yang baik dalam segala aspek kehidupan termasuk memberi pelajaran kepada umatnya agar senantiasa bekerja dan berusaha dalam mencukupi kebutuhan hidupnya. Dalam hadits dikatakan:

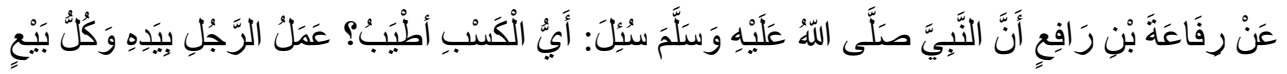

$$
\begin{aligned}
& \text { مَبْرُوْرِ. . روواه البزاروصححه الحاكمُ }
\end{aligned}
$$

"Rifa'ah bin Rafi'I berkata bahwa Nabi SAW ditanya, "Apa mata pencaharian yang paling baik?” Nabi menjawab, "Seseorang bekerja dengan tangannya dan tiap-tiap jual beli yang bersih." (Diriwayatkan oleh Bazzar dan disahkan oleh Hakim)

Dari hadits di atas, dapat dipahami bahwa sangat tidak dianjurkan jika seseorang ingin memiliki kehidupan yang cukup tapi hanya menadahkan tangan berharap rezeki turun dari langit tanpa ada usaha. Namun, tidak dibenarkan pula jika hanya mengandalkan kemampuan usaha tanpa diiringi do'a serta memohon pertolongan Allah SWT. Hal tersebut tidak sedikit terjadi di sekeliling kehidupan kita, masih banyak yang terlarut dalam pekerjaannya tanpa sadar bahwa ada yang yang selalu membantunya di balik kemampuannya, atau sebaliknya yang hanya mengandalkan do'a berharap mendapatkan hasil tanpa mau bekerja keras untuk mendapatkannya. Padahal, Allah menciptakan segala apa yang ada di bumi ini tidak ada yang sia-sia, semuanya bisa dimanfaatkan oleh manusia, diolah dan dikelola sebaik mungkin hingga menjadi sumber penghasilan kehidupan atau bahkan tercipta lapangan pekerjaan untuk orang lain.

Banyak ayat Al-Qur'an tentang perintah kepada manusia untuk memanfaatkan apa-apa yang ada di bumi sebagai bekal hidup, di antaranya:

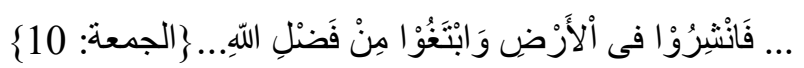

“...Maka bertebaranlah kamu di muka bumi, dan carilah karunia Allah...” (QS. Al-Jumu'ah: 10) ${ }^{6}$

$$
\text { وَجَعَلْنَا النَّهَارَ مَعَانثًا . . }
$$

\footnotetext{
${ }^{6}$ Al-Qur'an Maghfirah (Jakarta: Maghfirah Pustaka), hlm. 554
} 
“Dan kami jadikan siang untuk mencari penghidupan.” (QS. An-Naba: 11) ${ }^{7}$

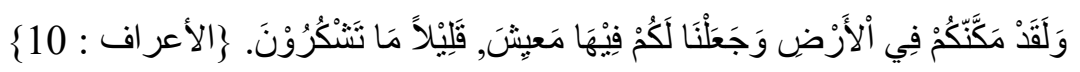

"Sesungguhnya Kami telah menempatkan kamu sekalian di muka bumi dan

Kami adakan bagimu itu (sumber) penghidupan. Amat sedikitlah kamu bersyukur." (QS. Al-A'raf: 10) ${ }^{8}$

Ayat-ayat di atas nampak jelas perintah untuk mencari penghidupan dan bekerja keras agar mencapai kemajuan dari apa yang diinginkan. Maka untuk meraih kemakmuran sesorang tentu akan bekerja keras dengan segala potensi dan kemampuan yang dimilikinya, sehingga tidak sedikit orang yang tidak beriman kepada Allah SWT, namun semangat dan berambisi kuat untuk mendapatkan kemakmuran di dunia (meski di akhirat tetap celaka). Pun sebaliknya, ada yang sangat beriman kepada Allah SWT, namun enggan berusaha dan bekerja sehingga sulit untuk menemukan kemakmuran. Itulah sebabnya mengapa keduanya (dunia dan akhirat) harus seimbang, agar di dunia mendapatkan kemakmuran, pun di akhirat mendapat kesenangan pula serta bebas dari celaka. Menerapkan pola pikir yang demikian memang tidak mudah, perlu adanya kesadaran dari setiap diri masing-masing bahwa dalam mencapai sesuatu yang kita inginkan tidak ada yang instan, semuanya perlu proses dan kerja keras.

Oleh karena itu, sebagai seorang muslim sudah selayaknya memanfaatkan segala kemampuan yang Allah berikan pada diri untuk mencari rezeki dengan segala kekuatan yang ada. Namun, dalam mencarinya perlu diperhatikan halal atau haramnya, tidak hanya mengutamakan hasil yang banyak semata, tanpa memerhatikan aturan-aturan yang ditetapkan dalam syari'at Islam. Tidak ada pekerjaan yang dilarang selama tidak bertentangan dengan syari'at Islam, dan dalam bekerja dianjurkan menggunakan tangan dan kemampuan serta keahlian yang dimiliki, sebagaimana penjelasan hadits di atas merupakan pekerjaan yang paling baik. ${ }^{9}$ Dalam hadis yang lain dinyatakan:

\footnotetext{
${ }^{7}$ Al-Qur'an Maghfirah (Jakarta: Maghfirah Pustaka), hlm. 582

8 Al-Qur'an Maghfirah (Jakarta: Maghfirah Pustaka), hlm. 151

${ }^{9}$ Rachmat Syafe'i. Al-Hadis: Aqidah, Akhlaq, Sosial, dan Hukum. (Bandung: Pustaka Setia,
} 2000), hlm. 115 


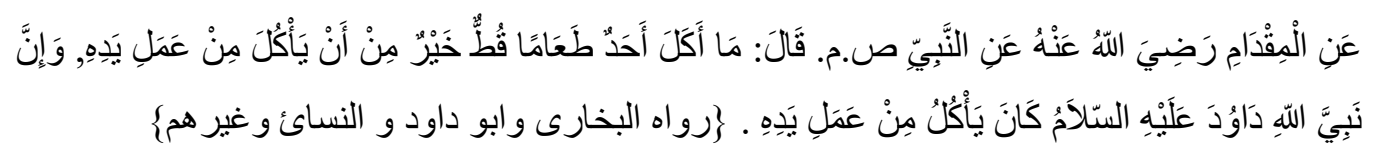

"Dari Miqdam r.a., Nabi SAW telah bersabda, "Tidaklah sesorang makan sesuatu lebih baik daripada makanan yang dihasilkan melalui tangannya (usahanya) sendiri. Dan sungguh Nabi Daud A.S telah makan dari hasil tangannya.” (HR. Bukhari, Abu Dawud, Nasai, dan lain-lain)

Harta, bisa saja didapatkan dari pemberian orang tua, kerabat, bahkan warisan. Namun harta yang paling baik adalah harta hasil jerih payah sendiri. Hadis di atas lebih menegaskan bahwa seseorang yang bekerja menggunakan tangannya sendiri, memanfaatkan kemampuan yang dimiliki sangat lebih mulia serta hasil yang didapat pun akan lebih berharga walau sedikit, daripada harta warisan atau hasil pemberian orang lain. Allah sangat menghargai orang-orang yang senantiasa bekerja keras dalam hidupnya, bahkan Allah akan menghapus dosa orang yang bersungguh-sungguh dalam bekerja. Sebagaimana hadis berikut:

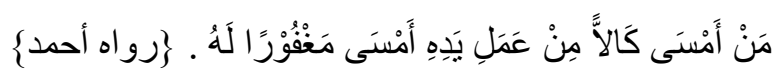

"Barang siapa yang merasa letih di malam hari karena bekerja, maka di malam itu ia diampuni." (HR. Ahmad) ${ }^{10}$

Selain Allah akan mengampuni dosanya, Islam juga melindungi dan menjamin mereka yang bekerja keras dengan memberi penegasan kepada para majikan agar senantiasa menghargai orang yang bekerja pada mereka. Sehingga dalam hadis lain dikatakan:

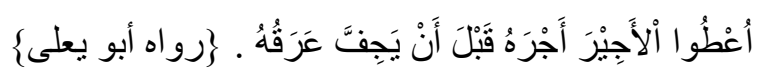

"Berikanlah gaji kepada pekerja sebelum kering keringatnya." (HR. Abu Ya'la)

Banyak hikmah yang dapat diambil dari rezeki yang didapat dari hasil tangan sendiri. Salah satunya mengajarkan kita bagaimana lelahnya bekerja sehingga akan lebih menghemat dalam pemakaiannya. Pekerjaan yang baik adalah pekerjaan yang dilakukan dengan tidak bertentangan dengan syariat Islam. Contoh dalam berjualan, perlu dilakukan dengan cara yang baik, tidak

\footnotetext{
2000), hlm. 116

${ }^{10}$ Rachmat Syafe'i. Al-Hadis: Aqidah, Akhlaq, Sosial, dan Hukum. (Bandung: Pustaka Setia,
} 
mengutamakan mendapat keuntungan yang besar tanpa memerhatikan kejujuran dan melanggar aturan agama, tidak mengurangi timbangan, tidak berbohong, menipu, dan lainnya. Karena pada hakikatnya, apa-apa yang kita kerjakan akan dimintai pertanggungjawaban di hadapan Allah SWT, sekecil apapun itu.

\section{Larangan Meminta-Minta}

Dalam hadis dikatakan:

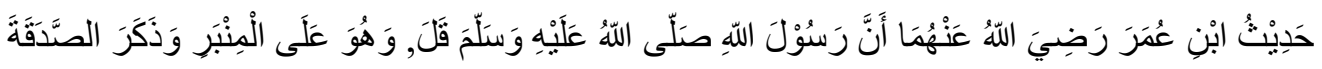

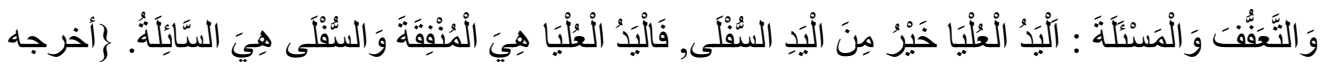

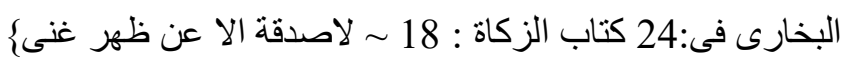

"Ibnu Umar r.a berkata, "Ketika Nabi SAW berkhotbah di atas mimbar dan menyebut sedekah dan minta-minta, beliau bersabda, "Tangan yang di atas lebih baik daripada tangan yang di bawah, tangan yang di atas memberi dan tangan yang di bawah meminta." (Dikeluarkan oleh Imam Bukhari dalam “Kitab Zakat” bab “Tidak ada zakat kecuali dari orang yang kaya.”)

Islam memuliakan pekerja keras dan mencela orang yang memikiki kemampuan, memiliki badan yang sehat dan kuat, namun tidak mau berusaha dan bekerja, hanya menggantungkan hidupnya pada orang lain. Menghrap diberi, bahkan meminta-minta. Selain merendahkan dirinya, secara tidak langsung ia pun merendahkan ajaran agamanya yang sudah sangat jelas bahwa perbuatan tersebut dilarang dalam ajaran Islam. Bisa dikatakan bahwa seorang peminta-minta adalah orang yang kufur nikmat, karena ia diberi kekuatan sehat jasmani dan rohani tetapi tidak dipergunakan dengan baik untuk mencari rezeki sebagaimana yang diperintahkan syara'. ${ }^{11}$ Padahal, semua makhluk yang ada di bumi ini Allah beri rezeki, jangankan manusia atau hamba-Nya, semut kecil tak terlihat pun telah Allah tetapkan rizkinya tinggal bagaimana cara kita menjemput rezeki itu. Allah SWT berfirman dalam surat Hud ayat 6, "Dan tidak ada suatu binatang melata pun di bumi melainkan Allah lah yang beri rezekinya, dan Dia

${ }^{11}$ Rachmat Syafe'i. Al-Hadis: Aqidah, Akhlaq, Sosial, dan Hukum. (Bandung: Pustaka Setia, 2000), hlm. 122 
mengetahui tempat berdiam binatang itu dan tempat menyimpannya ${ }^{12}$. Semuanya tertulis dalam kitab yang nyata (lauh Mahfuzh)." (QS. Hud : 6) ${ }^{13}$ Rasulullah SAW juga bersabda:

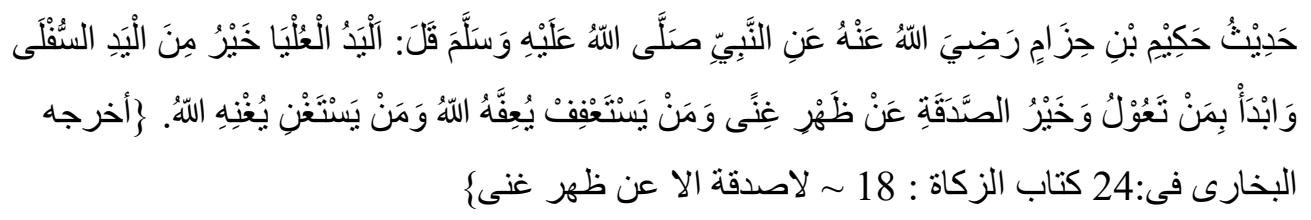

Hakim bin Hazim berkata, "Nabi SAW bersabda, "Tangan yang di atas lebih baik daripada tangan yang di bawah, dan dahulukan keluargamu (orang yang wajib kamu beri belanja), dan sebaik-baiknya sedekah itu dari kekayaan (yang berlebihan), dan siapa yang menjaga kehormatan diri (tidak minta-minta), maka Allah akan mencukupinya, demikian pula siapa yang beriman merasa sudah cukup, maka Allah akan membantu memberinya kekayaan." (Dikeluarkan oleh Imam Bukhari dalam "Kitab Zakat” bab "Tidak ada zakat kecuali dari orang yang kaya.")

Dalam hadits ini terdapat singgungan mengenai etika memberi sesuatu kepada orang lain, yakni harus lebih mengutamakan keluarga yang merupakan tanggungjawabnya, kerabat terdekat, dan seterusnya. Begitupun dengan sesuatu yang diberikannya, haruslah dari rezeki yang lebih. Maksudnya, jangan sampai mengedepankan memberi orang lain, sedangkan diri sendiri dan keluarga kesusahan. Karena kita berada pada zaman 4.0, yang persaingan pekerjaan semakin ketat, ternyata masih banyak orang yang lebih senang mengemis daripada bekerja. Hal ini sangat merajalela di mana-mana, terlebih di tempattempat penziarahan dan di jalan-jalan. Padahal, Rasulullah sudah sangat tegas dalam hal ini. Ini sangat menyedihkan jika diperhatikan, orang sehat, kuat, mampu berdiri tegak, berlari masih kencang, berkata masih lancar, tetapi seringkali berlaga sekan tidak mampu apa-apa hanya agar dikasihani orang. Na'udzubilahi min dzalik

\footnotetext{
${ }^{12}$ Menurut sebagian mufasir, yang dimaksud "tempat kediaman" di sini adalah dunia, dan "tempat penyimpanan" ialah akhirat. Dan menurut sebagian mufasir lain, maksud "tempat kediaman" ialah tulang sulbi, dan "tempat penyimpanan" ialah rahim.

${ }^{13}$ Al-Qur'an Maghfirah (Jakarta: Maghfirah Pustaka), hlm.222
} 
Melihat keadaan sebagaimana di atas, dapat kita cerna bahwa mungkin pemulung lebih mulia daripada peminta. Rasulullah SAW bersabda:

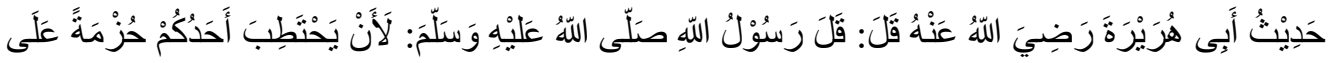

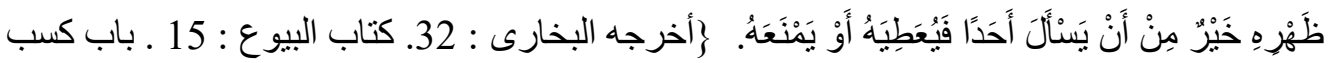

$$
\begin{aligned}
& \text { الرجل و عمله بيده؛ }
\end{aligned}
$$

"Abu Hurairah r.a berkata: Rasulullah SAW bersabda, "Jika seorang itu pergi mencari kayu, lalu diangkat seikat kayu di atas punggungnya (yakni untuk dijual di pasar), maka itu lebih baik bagimu daripada minta kepada seseorang baik diberi atau ditolak." (Dikeluarkan oleh Imam Bukhari dalam kitab, "Jual Beli Buyu” bab “Kasab seorang laki-laki dan bekerja dengan tangannya sendiri.”)

Seseorang yang sebagaimana hadis di atas walaupun seringkali pekerjaannya dipandang hina di mata manusia serta penghasilannya tidak banyak, lebih mulia daripada yang mendapat banyak tetapi hasil dari memintaminta, lalu-lalang di jalanan siang malam mengemis kepada manusia, yang sebenarnya mereka mampu untuk bekerja mencari nafkah dengan cara yang baik.

Adanya kewajiban bekerja ini tidak berarti bahwa Allah SWT tidak memiliki kuasa untuk memberikan rezeki begitu saja kepada makhluk-Nya, tetapi agar manusia memahami dan menghargai dirinya serta kemampuan yang Allah karuniakan kepadanya agar disyukuri dan dimanfaatkan sebaik mungkin, sekaligus agar manusia tidak berlaku semena-mena atau melampaui batas. ${ }^{14}$

\section{Mukmin Yang Kuat Mendapat Pujian}

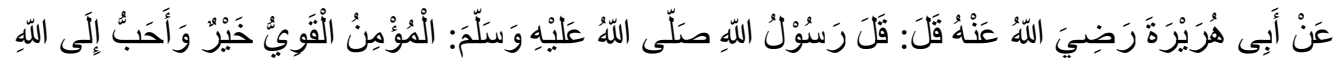

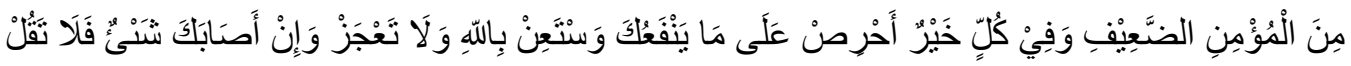

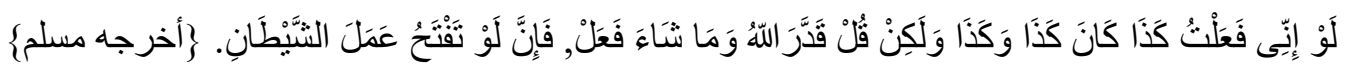

"Abu Hurairah r.a berkata bahwa Rasulullah SAW bersabda, "Orang mukmin yang kuat lebih baik dan lebih dicintai Allah daripada mukmin yang lemah dan dalam sesuatu, ia dipandang lebih baik. Raihlah apa yang memberikan manfaat

\footnotetext{
${ }^{14}$ Rachmat Syafe'i. Al-Hadis: Aqidah, Akhlaq, Sosial, dan Hukum. (Bandung: Pustaka Setia, 2000), hlm. 124
} 
bagimu. Minta tolonglah kepada Allah. Janganlah lemah! Kalau engkau tertimpa sesuatu, janganlah berkata, 'Kalau aku berbuat begini, pasti begini dan begitu, tetapi katakanlah, "Allah SWT telah menentukan dan Allah menghendaki aku untuk berbuat karena (kata) "kalau” akan mendorong pada perbuatan setan.” (HR. Muslim)

\section{Memperkuat Iman}

Tingkat keimanan seseorang tidaklah sama, ada yang kuat dan lemah. Orang yang imannya kuat biasanya ditandai dengan sifat taatnya terhadap apa yang diperintahkan Allah SWT, senantiasa menjaga ibadahnya, menjalankan amar ma'ruf nahi munkar, dan lainnya. Sedangkan yang imannya lemah seringkali ditandai dengan kemalasannya menjalankan kewajiban sebagai seorang muslim, melalaikan ibadah, dan tentunya berlawanan dengan sifat seorang yang kuat imannya seperti yang disebutkan di atas. Kuat dan lemahnya iman juga berpengaruh terhadap kehidupan, termasuk ekonomi dan kekayaan. Karena yang kuat iman biasanya memiliki jiwa yang semangat untuk melakukan segala hal kebaikan, berbeda dengan yang imannya lemah, melakukan apapun akan terasa berat dan malas. Sekalipun dikerjakan, tidak dengan kesungguhan. Rasulullah SAW menyeru kepada orang yang beriman agar senantiasa memperindah keimanannya dengan segala kebaikan dan amal shaleh serta memelihara badannya agar tetap kuat sebagai bekal untuk beribadah dan bekerja keras serta berusaha sehingga kehidupannya tidak susah. Tentu juga agar tetap berusaha menjaga diri dari segala bentuk kemaksiatan agar mendapatkan kebahagiaan dunia dan akhirat.

\section{Perintah Untuk Memanfaatkan Waktu}

Di antara nikmat besar yang sering dilalaikan manusia adalah nikmat waktu luang. Bisa kita lihat sendiri, ketika ada waktu luang, justru malah digunakan dengan hal-hal yang kurang atau bahkan tidak bermanfaat. Tidak manfaat untuk kehidupan dunia bahkan akhirat. Terlebih anak muda zaman sekarang, mereka menghabiskan waktu dengan bermain game seharian, nonton 
film, bolak-balik sosial media, yang isinya sama sekali tidak berfaidah. ${ }^{15}$ Padahal, sangat banyak aktivitas yang dapat dikerjakan seorang muslim yang lebih bermanfaat, seperti belajar, mencari ilmu, membaca, mencari rezeki yang halal, dan lainnya. Dalam kehidupan bermasyarakat, orang yang sukses adalah orang yang senantiasa memanfaatkan waktunya dengan kegiatan yang bermanfaat, tidak menghambur-hamburkan waktu secara sia-sia. Karena time is money (waktu adalah uang), artinya waktu itu sangat berharga jika dilewatkan satu detik pun dengan kegiatan yang kurang berfaidah. Ada pepatah Arab menyatakan:

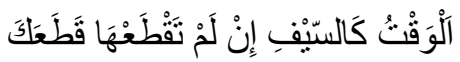

"Waktu itu bagaikan pedang, jika kamu tidak memanfaatkannya (menggunakannya untuk memotong), ia akan memotongmu (menggilasmu).,

\section{Memohon Pertolongan Allah SWT}

Sesorang tidak akan mencapai kesuksesan tanpa pertolongan dan kekuasaan Allah SWT. Karena pada hakikatnya, manusia hanya diwajibkan untuk berusaha atau ikhtiar, berhasil tidaknya tetap Allah yang memiliki kekuasaan. Oleh karenanya, setiap apa-apa yang kita usahakan perlu diiringi do'a sebagai wujud permohonan pertolongan-Nya agar apa yang kita usahakan berbuah hasil sebagaimana yang diinginkan, karena Allah SWT pun tidak akan menyia-nyiakan ikhtiar dan pekerjaan seseorang yang sungguh-sungguh karena Allah.

\section{Larangan Membiarkan Kelemahan}

Di atas telah dijelaskan tentang bagaimana Islam melarang keras umatnya untuk bermalas-malasan, dan senantiasa memerintahkan untuk selalu bekerja dan berusaha agar menjadi orang yang kuat dalam segala hal. Kuat iman, jasmani dan rohani, ekonomi, dan lain-lain. Karena sungguh, kelemahan seseorang itu berawal dari sebuah kemalasan. Setiap orang harus berusaha untuk

\footnotetext{
${ }^{15}$ https://muslim.or.id/37903-memenfaatkan-waktu-luang-untuk-hal-hal-yang-bermanfaat.html
} 
mengubah segala kelemahan yang ada pada diri masing-masing, karena Allah tidak akan mengubahnya kecuali pribadinya berusaha untuk mengubahnya.

\section{Larangan untuk Menyatakan "Kalau" (seandainya begini dan begitu pasti hasilnya begini)}

Sebagaimana dikatakan di atas, manusia hanya ikhtiar, hasil akhir nya Allah yang menentukan. Oleh karenanya, dalam berusaha tidak selamanya selalu berhasil, akan ada waktu menjumpai sebuah kegagalan sebagai penguji mental diri dalam menyikapinya. Yang jika hal ini terjadi, tentu yang harus dilakukan adalah menyerahkan sepenuhnya kepada yang lebih berkuasa, Allah SWT, karena sudah menjadi kehendak-Nya. Pernyataan kalau begini dan begitu merupakan suatu godaan setan untuk mendahului ketetapan atau kehendak Allah SWT.

\section{Kesimpulan}

Sebenarnya, etos kerja dalam persprktif Islam merupakan nilai-nilai etis yang terkandung dalam Al-Qur'an dan As-Sunnah mengenai kewajiban dan keutamaan bekerja. Ajaran Islam sudah sangat jelas memberikan motivasi dan inspirasi kepada umatnya agar bekerja sebaik mungkin untuk mencapai hasil yang terbaik. Dalam implementasinya, di lingkungan sekeliling saja masih banyak yang jauh dari kesadaran bahwa etos kerja itu sangat penting untuk diterapkan dalam dunia pekerjaan atau dalam kehidupan. Karena hasil kerja yang baik ada pada diri seseorang yang yang menanamkan nilai etos kerja dalam kehidupannya.

\section{DAFTAR PUSTAKA}

Clifford. 2000. Kebudayaan dan Agama. Yogyakarta: Kanisius

Suharso dan Ana Retnoningsih. 2009. Kamus Besar Bahasa Indonesia. Semarang: CV Widya Karya

Nurcholis Madjid.1995. Islam Agama Kemanusiaan: Membangun Tradisi dan Visi Baru Islam Indonesia. Jakarta: Pramadina

Tasmara, Toto. 1995. Etos Kerja Pribadi Muslim. Yogyakarta: Dana Bhakti Prima Yasa 
Al-Qur'an Maghfirah. Jakarta: Maghfirah Pustaka

Syafe'I, Rachmat. 2000. Al-Hadis: Aqidah, Akhlaq, Sosial, dan Hukum. Bandung: Pustaka Setia

Santoso, Eko Jalu. 2012. Good Ethos: 7 Etos Kerja Terbaik dan Mulia. Jakarta: PT. Elex Media Komputindo

Purkon, Arip. 2014. Kerja Berbuah Surga. Jakarta: PT. Gramedia Pustaka Utama

https://muslim.or.id/37903-memenfaatkan-waktu-luang-untuk-hal-halyang-bermanfaat.html 